\title{
Efektivitas Ekstrak Daun Ceplukan sebagai Antimikroba terhadap Methicillin-Resistant Staphylococcus aureus In Vitro
}

\section{Effectiveness of Ceplukan Leaf Extract as Antimicrobial for Methicillin-Resistant Staphylococcus aureus In Vitro}

\author{
Dwi Fitrianti $A R^{1}$, Noorhamdani $A S^{2}$, Setyawati S Karyono ${ }^{3}$ \\ ${ }^{1}$ Program Studi Pendidikan Dokter Fakultas Kedokteran Universitas Brawijaya Malang \\ ${ }^{2}$ Laboratorium Mikrobiologi Fakultas Kedokteran Universitas Brawijaya Malang \\ ${ }^{3}$ Laboratorium Farmakologi Fakultas Kedokteran Universitas Brawijaya Malang
}

\begin{abstract}
ABSTRAK
Methicillin-resistant Staphylococcuc aureus (MRSA) merupakan bakteri Staphylococcus aureus yang multi resisten terhadap antimikroba. Tumbuhan ceplukan (Physalis angulata $L$ ) dapat dijadikan sebuah alternatif pengobatan infeksi MRSA karena pada umumnya memiliki senyawa aktif yang berperan sebagai senyawa antimikroba. Penelitian ini bertujuan untuk mengetahui efektivitas ekstrak daun ceplukan sebagai antimikroba terhadap MRSA in vitro. Metode yang digunakan adalah dilusi tabung untuk menentukan Kadar Hambat Minimum (KHM) dan Kadar Bunuh Minimum (KBM). Konsentrasi ekstrak daun ceplukan yang digunakan pada penelitian adalah 50\%; 55\%; 60\%; 65\%, 70\%, serta 2 kelompok kontrol yaitu kelompok kontrol bakteri tanpa diberi ekstrak daun ceplukan (0\%) dan kelompok kontrol bahan (100\%). Hasil dari penelitian ini didapatkan pertumbuhan koloni bakteri yang lebih rendah pada pemberian ekstrak daun ceplukan dibandingkan kontrol dan jumlah koloni semakin rendah dengan meningkatnya konsentrasi ang $(r=-0,770)$. Dapat disimpulkan bahwa ekstrak daun ceplukan memiliki efektivitas sebagai antimikroba terhadap bakteri MRSA secara in vitro.
\end{abstract}

Kata Kunci: Antimikroba, ekstrak daun ceplukan (Physalis angulata L.), Methicillin-resistant Staphylococcus aureus (MRSA)

\section{ABSTRACT}

Methicillin-resistant Staphylococcuc aureus (MRSA) is type of Staphylococcus aureus resistant to multiple antimicrobials. Ceplukan plant (Physalis angulata L) can be used as an alternative treatment for MRSA infections due to its active compounds that act as antimicrobial. This study aims to determine the effectiveness of Ceplukan leaf extracts as antimicrobials for MRSA in vitro. The method using dilution tube to determine the Minimum Inhibitory Levels (MIC) and Minimum Lethal Dose (MLD). Concentration of ceplukan leaf extract used in the study was 50\%, 55\%, 60\%, 65\%, 70\%, and 2 control group consist of a one prearation of bacteria without Ceplukan leaf extract (0\%) and control material (100\%). The results show that the number of MRSA bacterial colony is lower with the administration of leaf ceplukan extract, and the higher the concentration the lower the number of colony $(r=-0,770)$. It can be concluded that the Ceplukan leaf extract has the effectiveness as an antimicrobial against MRSA bacteria in vitro.

Keywords: Antimicrobial agent, ceplukan's leaf extract (Physalis angulata L.), Methicillin-Resistant Staphylococcuc aureus (MRSA)

Jurnal Kedokteran Brawijaya, Vol. 26, No. 4, Agustus 2011; Korespondensi: Noorhamdani AS. Laboratorium Mikrobiologi Fakultas Kedokteran Universitas Brawijaya Malang, Jl.Veteran Malang, Tel. (0341)569117Email:noorhamdanias@yahoo.com 


\section{PENDAHULUAN}

Kebijakan kesehatan dalam pengobatan infeksi bakteri berakibat pada resistensi antimikroba yang semakin meluas di seluruh dunia dan berkembang menjadi masalah kesehatan (1). MRSA merupakan galur spesifik dari bakteri Staphylococcus aureus yang resisten terhadap antimikroba semua turunan penicillin dan methicillin serta antimikroba spektrum luas betalactamase resisten penicillin (2).

Usaha untuk mencari sumber antimikroba baru, terutama yang berasal dari bahan alam atau tanaman indigenus yang terdapat di Indonesia terus dilakukan (3). Kandungan fitokimia banyak terdapat pada bagian daun ceplukan (Physalis angulata L.) diantaranya bahan aktif polifenol, flavonoid, alkaloid (4). Bahan aktif fitokimia polifenol, flavonoid, dan alkaloid tersebut dilaporkan memiliki aktifitas antimikroba yang cukup baik (5).

Tujuan dari penelitian ini adalah untuk membuktikan efek ekstrak daun ceplukan (Physalis angulata L.) sebagai antimikroba terhadap MRSA secara in vitro. Melalui penelitian ini diharapkan dapat diperoleh pengobatan alternatif dengan menggunakan bahan alam di sekitar kita dengan efek samping yang lebih minimal dibandingkan obat sintetis yang dijual di pasaran serta dapat menambah koleksi bahan antimikroba alami

\section{METODE}

Penelitian ini merupakan penelitian eksperimental laboratorik secara in vitro. Pada penelitian ini, digunakan 5 macam konsentrasi perlakuan berbeda (50\%, 55\%, 60\%, $65 \%, 70 \%)$, serta 1 kontrol positif dan 1 kontrol negatif. Pembuatan ekstrak daun ceplukan dilakukan melalui proses pengeringan dan ekstraksi dengan etanol 96\%. Identifikasi bakteri MRSA dilakukan dengan media Chrom Agar Staphylococcus aureus, gram staining dan dengan antibiotik Cefoxitin. Pembuatan perbenihan cair bakteri pada kepadatan $10^{6} \mathrm{CFU} / \mathrm{ml}$.

Uji sensitivitas antimikroba terhadap MRSA menggunakan metode dilusi tabung. Disiapkan 5 tabung reaksi untuk masing-masing perlakuan (tabung 1 sampai 5), 1 tabung kontrol bahan (KB), dan 1 tabung kontrol bakteri (KK). Masing-masing tabung (tabung 1 sampai dengan tabung 5) diisi sediaan ekstrak daun ceplukan+aquadest steril dengan konsentrasi ekstrak daun ceplukan hasil penelitian eksplorasi yaitu 50\% (0,5 $\mathrm{ml}$ ekstrak+0,5 ml aquadest), 55\% (0,55 ml ekstrak+0,45 $\mathrm{ml}$ aquadest), $60 \%(0,6 \mathrm{ml}$ ekstrak $+0,4 \mathrm{ml}$ aquadest), $65 \%$ $(0,65 \mathrm{ml}$ ekstrak+0,35\% aquadest), dan $70 \%(0,7 \mathrm{ml}$ ekstrak+0,3 $\mathrm{ml}$ aquadest). Disiapkan tabung kontrol bahan (KB) dengan konsentrasi 100\% (0,1 ml ekstrak+0 ml aquadest) dan kontrol bakteri (KK) dengan konsentrasi $0 \%$ $(0 \mathrm{ml}$ ekstrak $+0 \mathrm{ml}$ aquadest). Tabung 1 sampai 5 serta kontrol bakteri (KK) masing-masing ditambahkan $1 \mathrm{ml}$ suspensi MRSA dengan konsentrasi $10^{6} \mathrm{CFU} / \mathrm{ml}$. Semua tabung diinkubasi selama $18-24$ jam dengan suhu $37^{\circ} \mathrm{C}$, hari kedua semua tabung dikeluarkan dari inkubator. Diamati kekeruhan yang terjadi pada semua tabung dan tentukan KHM. Dari tabung yang tidak menunjukkan kekeruhan, diambil bakteri sebanyak 1 ose kemudian digoreskan pada Nutrient Agar Plate (NAP), dan diinkubasikan selam $18-24$ jam dengan suhu $37^{\circ} \mathrm{C}$. Pada penelitian ini dilakukan pengulangan sebanyak 4 kali. Jumlah koloni pada NAP dihitung dengan menggunakan colony counter dan ditentukan KBM, kemudian dianalisis dengan uji One Way ANOVA dan uji korelasi.

\section{HASIL}

\section{Identifikasi Bakteri MRSA}

Hasil identifikasi bakteri MRSA dengan pengecatan gram menunjukkan bakteri gram positif yaitu menunjukkan warna ungu dan berbentuk kokus. Pada chrom agar Staphylococcus aureus koloni yang terbentuk berwarna mouve. Dengan tes difusi cakram, bakteri MRSA memiliki zona hambat terhadap cakram antibiotika cefoxitin $30 \mu \mathrm{g}$ sebesar $<22 \mathrm{~mm}$.

\section{Efek Ekstrak Daun Ceplukan terhadap Bakteri MRSA}

Ekstrak daun ceplukan berwarna hijau kehitaman. Sebelum diinkubasikan warnanya sudah terlihat keruh sehingga pada penelitian ini tingkat kekeruhan masingmasing konsentrasi ekstrak tidak dapat diamati dan tidak dapat dianalisis secara kualitatif. Pada konsentrasi ekstrak yang paling rendah pun, terlihat keruh, meskipun apabila dibandingkan dengan konsentrasi yang lain tingkat kekeruhannya berbeda. Akibat kekeruhan tersebut, KHM ekstrak daun ceplukan terhadap bakteri MRSA ini tidak dapat ditentukan.

Hasil uji normalitas data secara keseluruhan, menunjukkan bahwa sebaran data terdistribusi normal $(p=0,470)$ sedangkan uji homogenitas menunjukkan bahwa data memiliki varians (ragam) populasi yang homogen $(p=0,300)$ sehingga memenuhi persyaratan uji One Way ANOVA. Hasil uji One Way ANOVA menunjukkan terdapat perbedaan jumlah koloni bakteri MRSA pada pemberian ekstrak daun ceplukan (Physalis angulata L.) dalam berbagai konsentrasi. Hasil uji Tukey dapat diketahui perbedaan yang signifikan antara masing-masing perlakuan variasi pemberian ekstrak daun Ceplukan terhadap pertumbuhan koloni bakteri MRSA pada media NAP kecuali pada konsentrasi $55 \%$ dan $60 \%$. Dari uji korelasi dapat diketahui bahwa semakin tinggi konsentrasi ekstrak daun Ceplukan (Physalis angulata L.) semakin rendah jumlah koloni bakteri $M R S A(r=-0,770 ; p=0,000)$.

Tabel 1. Jumlah koloni bakteri pada masing-masing konsentrasi ekstrak ceplukan (CFU/ml)

\begin{tabular}{ccccccc}
\hline \multirow{2}{*}{ Ulangan } & \multicolumn{5}{c}{ Konsentrasi Ekstrak Ceplukan \%) } & \multirow{2}{*}{ KK (10 $\left.\mathbf{1 0}^{\mathbf{4}}\right)$} \\
\cline { 2 - 6 } & $\mathbf{5 0 \%}$ & $\mathbf{5 5 \%}$ & $\mathbf{6 0 \%}$ & $\mathbf{6 5 \%}$ & $\mathbf{7 0 \%}$ & \\
\hline I & 70 & 49 & 37 & 18 & 0 & 213 \\
II & 77 & 45 & 39 & 23 & 0 & 237 \\
III & 79 & 41 & 37 & 21 & 0 & 253 \\
IV & 69 & 39 & 31 & 17 & 0 & 247 \\
Rerata & 73,75 & 43,5 & 36 & 19,75 & 0 & 2375 \\
\hline
\end{tabular}

\section{DISKUSI}

Hasil penelitian menunjukkan ekstrak daun ceplukan mempunyai efek antimikroba terhadap bakteri MRSA. Efek antimikroba diperkirakan diperankan oleh zat-zat aktif yang larut dalam alkohol, sebab metode ekstraksi penelitian ini menggunakan pelarut alkohol. Zat-zat aktif tersebut antara lain flavonoid, alkaloid, dan polifenol. Aktivitas flavonoid ini disebabkan oleh kemampuannya 
untuk membentuk kompleks dengan protein ekstraseluler dan terlarut, dan dengan dinding sel. Flavonoid yang bersifat lipofilik mungkin juga akan merusak membran sel mikroba. Rusaknya membran dan dinding sel akan menyebabkan metabolit penting di dalam sel akan keluar, dan mengakibatkan terjadinya kematian sel. Alkaloid merupakan senyawa nitrogen heterosiklik yang mengandung basa nitrogen. Mekanisme kerja dari alkaloid dihubungkan dengan kemampuan mereka untuk berinterkalasi atau meletakkan diri di antara DNA. Adanya zat yang berada di antara DNA akan menghambat replikasi DNA itu sendiri, akibatnya terjadi gangguan replikasi DNA yang menyebabkan kematian sel (5).

Mekanisme kerja polifenol pada mikroorganisme adalah sebagai inhibitor enzim oleh senyawa yang teroksidasi, kemungkinan melalui reaksi dengan grup sulfhidril atau melalui interaksi non-spesifik dengan protein. Hambatan pada enzim tersebut akan mengganggu fungsi enzim dan substratnya. Apabila fungsi enzim dan substrat terganggu lambat laun akan mengakibatkan kematian sel (6). Fenol berikatan dengan protein melalui ikatan hidrogen sehingga mengakibatkan struktur protein menjadi rusak. Oleh karena sebagian besar struktur dinding sel dan membran sitoplasma bakteri mengandung protein dan lemak, sehingga fenol diduga juga memiliki kemampuan untuk mendenaturasikan protein dan membran sel bakteri. Ketidakstabilan pada dinding sel dan membran sitoplasma bakteri menyebabkan fungsi permeabilitas selektif, fungsi pengangkutan aktif, pengendalian susunan protein dari sel bakteri menjadi terganggu (7).

Penelitian mengenai efektivitas antimikroba dari tanaman obat tradisional lainnya terhadap MRSA sudah pernah dilakukan. Dekok kulit jeruk nipis ternyata mampu menghambat pertumbuhan MRSA pada konsentrasi $18 \%$ dan mampu membunuh bakteri MRSA pada konsentrasi $20 \%$ (8). Ekstrak daun kayu putih juga mampu membunuh bakteri MRSA pada konsentrasi 3\% (9), sedangkan ekstrak kulit buah Delima mempu membunuh bakteri MRSA pada konsentrasi $0,8 \%$ (10). Metode yang digunakan sama dengan penelitian ini yaitu menggunakan uji dilusi tabung dan dilanjutkan dengan penggoresan pada media NAP. Dari beberapa hasil penelitian tersebut dapat disimpulkan bahwa walaupun bakteri MRSA merupakan salah satu bakteri yang resisten terhadap berbagai antimikroba, tetapi masih sensitif terhadap beberapa antimikroba dari bahan alam termasuk ekstrak daun ceplukan.

Pada penelitian mengenai efektivitas antimikroba dari ekstrak daun ceplukan (Physalis angulata L.) terhadap bakteri selain MRSA juga pernah dilakukan. Salah satunya penelitian sensitivitas ekstrak daun ceplukan (Physalis angulata $L$.) sebagai antimikroba terhadap Pseudomonas aeruginosa dengan metode yang sama yakni metode dilusi tabung dan penggoresan media NAP, dimana konsentrasi yang mampu membunuh bakteri Pseudomonas aeruginosa adalah 30\% (11). Pada penelitian ekstrak daun Ceplukan sebagai antimikroba terhadap MRSA didapatkan konsentrasi yang mampu

\section{DAFTAR PUSTAKA}

1. Hadi U, Kolopaking EP, Gardjito W, Gyssens IC, and Broek PJ. Antimicrobial Resistance and Antibiotic Use in Low-Income and Developing Countries. Folia Medica Indonesiana. 2006; 42(3): 183-195. membunuh MRSA adalah 70\%, terdapatnya perbedaan jumlah konsentrasi ini kemungkinan dikarenakan oleh perbedaan sensitivitas terhadap antimikroba yang berbeda antara bakteri MRSA dan Pseudomonas aeruginosa dimana bakteri MRSA menunjukkan resistensi yang lebih kuat, atau mungkin dikarenakan dari efek ekstrak daun ceplukan yang berbeda tingkat sensivitasnya sebagai antimikroba.

Dengan melihat fakta hasil penelitian yaitu adanya penurunan jumlah koloni bakteri MRSA yang tumbuh pada media NAP seiring dengan peningkatan konsentrasi ekstrak daun Ceplukan (Physalis angulata L.) serta diperkuat dengan adanya data bahwa daun Ceplukan mengandung bahan aktif yang mampu menghambat pertumbuhan bakteri MRSA, maka dapat dikatakan bahwa ekstrak daun Ceplukan terbukti memiliki efek antimikroba yang dapat menghambat pertumbuhan dan membunuh bakteri MRSA. Hal ini membuktikan bahwa hipotesis yang telah disusun sebelumnya benar terbukti.

Pada penelitian ini tidak dapat ditentukannya Kadar Hambat Minimum (KHM) karena ekstrak daun Ceplukan (Physalis angulata L.) yang terlalu keruh, oleh karena itu perlu penelitian lanjutan dengan cara pembuatan ekstrak yang lebih khusus. Untuk lebih mengetahui mekanisme kerja dari bahan-bahan yang terkandung dalam ekstrak daun Ceplukan (Physalis angulata L.) maka perlu penelitian dengan pemisahan/pemurnian bahan-bahan yang terkandung tersebut, sehingga dapat diketahui mana yang lebih menonjol efeknya sebagai antimikroba. Kemungkinan lainnya adalah variasi biologis dari masingmasing daun Ceplukan (Physalis angulata L.). Tanaman ceplukan yang ditanam di satu daerah mungkin efeknya tidak sama dengan tanaman Ceplukan yang ditanam di daerah lain. Faktor lain yang juga mempengaruhi adalah lamanya masa simpan ekstrak, semakin lama disimpan maka sensivitas ekstrak biasanya akan menurun, tetapi ada juga yang malah makin meningkat. Penelitian selanjutnya perlu ada standarisasi baik dari pemilihan bahan yang digunakan (daun ceplukan), lamanya masa simpan (jangka waktu ekstrak masih dapat digunakan sebagai antimikroba), maupun penentuan metode yang digunakan dalam penelitian.

Aplikasi klinis ekstrak daun ceplukan (Physalis angulata L.) sebagai antimikroba masih memerlukan penelitian lebih lanjut berupa penelitian in vivo. Hal ini dikarenakan belum ada penelitian medis mengenai dosis efektif, toksisitas, dan efek samping yang ditimbulkan ekstrak daun ceplukan. Dengan dasar tersebut maka perlu dilakukan suatu penelitian secara in vivo mengenai dosis, toksisitas, dan efek samping yang ditimbulkan ekstrak daun ceplukan pada hewan coba yang nantinya dapat diaplikasikan pada manusia. Dari hasil penelitian ini dapat disimpulkan bahwa ekstrak daun ceplukan (Physalis angulata L.) memiliki daya antimikroba terhadap bakteri Methicillin-resistant Staphylococcus aureus (MRSA) secara in vitro dengan kadar bunuh minimal pada konsentrasi $70 \%$.

2. Moran GJ, Krishnadasan A, Gorwitz RJ, et al. Methicillin-Resistant S. Aureus Infections among Patients in the Emergency Department. The New England Journal of Medicine. 2006; 355(7): 666-674.

3. Ardiansyah, Lilis Nuraida, dan Nuri Andarwulan. 
Antimicrobial Activity of Beluntas (Pluchea Indica L.) Leaves Extract and Stability of the Activity at Different Salt Concentrations and $\mathrm{pHs}$. Journal of Food Technology and Industry. 2003; 14; 90-97.

4. Taylor L. The Healing Power of Rainforest Herbs. MULLACA (Physalis angulata). (Online) 1996. http://www.rain-tree.com/book2.htm. [diakses tanggal 10 Desember 2007].

5. Naim R. Senyawa Antimikroba dari Tanaman. (Online) 2008. http://kompas.com/kompas-cetak/ contactus.htm. [diakses tanggal 3 Januari 2008].

6. Dahlan MS. Statistik untuk Kedokteran dan Kesehatan: Deskriptif, Bivariat, dan Multivariat Dilengkapi Aplikasi dengan Menggunakan SPSS. Edisi 3. Jakarta: Penerbit Salemba Medika; 2008.

7. Susanti A, Rimayanti I, dan Sukmanadi M. Daya
Antibakteri Ekstrak Etanol Daun Beluntas (Pluchea indica less) terhadap Escherichia coli secara In Vitro. Veterineria Medika. 2008; 1(1): 4.

8. Fanani E. Efek Dekok Kulit Jeruk Nipis sebagai Antimikroba terhadap MRSA. [Skripsi]. Universitas Brawijaya, Malang. 2006.

9. Pramulia IR. Efektivitas Ekstrak Daun Kayu Putih terhadap Pertumbuhan MRSA. [Skripsi]. Universitas Brawijaya, Malang. 2005.

10. Kartini R. Aktivitas Antimikroba Ekstrak Ethanol Kulit Buah Delima terhadap Pertumbuhan MRSA. [Skripsi]. Universitas Brawijaya, Malang. 2006.

11. Sudarto ACAS. Sensivitas Ekstrak Daun Ceplukan sebagai Antimikroba terhadap Pseudomonas aeruginosa. [Skripsi]. Universitas Brawijaya, Malang. 2009. 